Historic, Archive Document

Do not assume content reflects current scientific knowledge, policies, or practices. 



\section{SOME POINTERS ON}
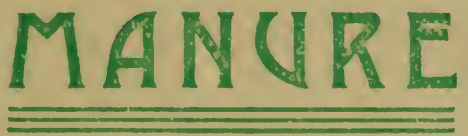

$$
51908 ?=
$$

WHAT IS THE DIFFERENCE BETVEEH

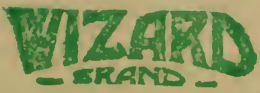

AND OTEER IKWDS?

THE ELM CITY NURSERY CO. ' N'EW HAVEN, CONRECTICUT,

Special Agents.

MANUTACTURED BY

THE PULVERIZED MANURE CO. CHICAGO 


\section{THE BARNYARD}

vS.

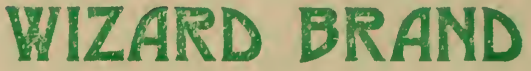

Rough Barnyard or Stable Manure contains from 60 to $75 \%$ of water. This leaves but 25 to 40 pouncis of useful matter in every hundred pounds, or bur 500 to 800 pounds in every ton you handle.

DO YOU WANT TO BUY AND HANDLE WATER FOR FERTILIZING?

WIZARD BRAND Manures contain less than $4 \%$ of moisture. This means that weight and bulk is reduced and that you get over 1920 pounds of dry valuable material in every ton.

Rough Manures, as they generally are available to the man who wants to fix up his lawn and garden or use them in his greenhouse, contain from 50 to 6018 of hay or straw bedding-with plenty of any old kind of weed seed mixed in and ready for just half a chance to crowd out every thing else that grows.

DO YOU WANT TO BUY HAY AND STRAW AND A CROP OF WEEDS?

WIZARD BRAND Pulverized Manure has no straw or rough stuff in it. It is ground up fine and works into the soil readily and rapidly. Every ounce is valuable as a plant food and soil builder. Wizard Brand Shredded Manure has less than five pounds of short straw in a 100-pound bag. The high quick hent in the drying process destroys the germ in any seeds thero may be and it brings yow no weode to fight. 
Government reports which are accurate and authoritative show that Fresh Barnyard Manure contains :

WATER ...........................................40 to $65 \%$

NITROGEN .................................1/2 to $3 / 4$ of 18

PhosphoRIC ACID........................1/5 to $2 / 5$ of 1 ;

POTASH..................................1/3 to $1 / 2$ of 18

These are the valuable plant growing PROPERTIES IN MANURE.

An analysis of WIZARD BRAND Manuro shows :

WATER . . . . . . 3 to $d s$ NITROGEN . . . $21 / 10$ to $31 / 28$ PHOSPHORIC ACID . $12 / 10$ to $17 / 10 \%$ POTASH . . . $11 / 3$ to $21 / 4 \%$

THIS IS THE MINIMUM OF WEIGHT AND BULK AND THE MAXIMUM OF GOOD AND VALUABLE MATERIAL.

Rough Manure is disagreeable to handle and apply, is objectionable on lawns and gardens because it is foul smelling and unsightly and is blown over walks and tracked into the house just as long as it remains scattered about. Sooner or later it has to be raked up and carted away and your soil has actually retained but a small fraction of the good your labor and expense calls for.

WIZARD BRAND has none of these dis* agreeable features because you get only the efficient and valuable part of the material in the most concentrated and wholly available form.

It is manufactured from carefully selected cleanings from brick paved pens, is free from sand, dirt and cinders, an absolutely pure product of the highest possible grace. Packed in bags of 100 pounds each it is convenient and cleanly, and can be applied by any one. Use it on anything you grow and results will prove our claims. 


\section{WIZARD BRAND MANURE}

BEST FOR

LAWN

FLOWER GARDEN

VEGETABLE GARDEN GREENHOUSE

NURSERY

O FCHARD

VINEYARD

SMALL FRUIT\&

BERRIES

AND ALL GENERAL FERTILIZING RFFICIENT

ECONOMICAL

EASILY APPLIED

MAXIBUM GOOD

AT MINIMUM EXPENSE

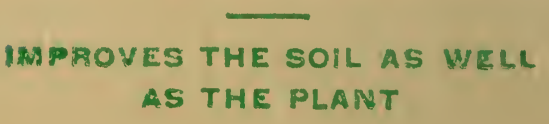

